\title{
Reprezentacja aktorów niepaństwowych w Unii Europejskiej a polska racja stanu ${ }^{1}$
}

Podejmując się próby analizy realizowanych działań lobbingowych przez aktorów niepaństwowych w ramach polskiej racji stanu na poziomie europejskim wobec poszczególnych organów Unii Europejskiej należy najpierw zdefiniować: polską rację stanu (polskie interesy - interesy narodowe), priorytety polskich interesów w Unii Europejskiej, realizację polskiego interesu na poziomie europejskim.

Procesy decyzyjne na poziomie Unii Europejskiej (UE) można podzielić na trzy podstawowe etapy: kreowanie polityki, decydowanie polityczne oraz wdrażanie do systemu prawnego poszczególnych aktów prawa wtórnego - implementacja na poziomie unijnym (Tosiek, 2007, s. 100-101). Uwzględniając powyższe najbardziej istotną fazą z punktu widzenia lobbingu prowadzonego przez aktorów niepaństwowych ma etap implementacyjny. W procesie tym biorą aktywnie udział zarówno poszczególne państwa członkowskie, instytucje i organy UE [Komisja Europejska (KE), Parlament Europejski (PE) i Rada (Rada Unii Europejskiej - RUE) oraz poszczególne komitety - Komitet Regionów (KR) czy Europejski Komitet Ekonomiczno-Społeczny (EKES)], a także aktorzy niepaństwowi mający znaczący wpływ na jego proces. Kluczowym organem na poziomie unijnym jest KE, która pełni jedną z najważniejszych funkcji w procesie podejmowania inicjatywy prawodawczej [z inicjatywy własnej (Traktat o Unii Europejskiej, 2012, art. 17 ust. 2)]. W ujęciu pragmatycznym rola wspomnianych instytucji i organów sprowadza się głównie do procedowania aktów prawnych (KE: inicjatywa prawodawcza, nadzór; Rada i PE: procedowanie w ramach procesu implementacyjnego i decyzyjnego) oraz opiniowania projektów aktów prawnych (w przypadku KR i EKES), a także wykonywania poleceń KE np. agencje wykonawcze [delegowania uprawnień (Peterson, Shackleton, 2012, s. 220-225)]. W związku z tym, że w systemie instytucjonalnym Unii Europejskiej ścierają się różnorodne interesy, to w proces decyzyjny, prawodawczy i implementacyjny są zaangażowani wspomniani powyżej poszczególni aktorzy niepaństwowi (sektorowi i niesektorowi) reprezentujący szerokie spektrum tożsamych lub odmiennych interesów (Parkinson, 1958, s. 122).

\section{Polska racja stanu (interesy narodowe)}

Do tej pory głównymi obszarami badawczymi dotyczącymi aktorów niepaństwowych weryfikowanymi przez różnych naukowców była głównie analiza dotycząca

${ }^{1}$ Przygotowanie tego artykułu zostało sfinansowane w ramach programu Ministra Edukacji i Nauki pod nazwą „DIALOG” w latach 2019-2021. 
funkcjonowania interesariuszy w ramach różnych systemów politycznych zarówno na poziomie światowym, europejskim (UE), jak i krajowym. Ponadto badacze zajmowali się głównie analizą poszczególnych grup interesu niż wpływem niezależnych zjawisk takich jak: lobbing na rzecz racji stanu poszczególnych państw w Unii Europejskiej, analiza struktury procesu decyzyjnego, relacje pomiędzy tymi podmiotami a instytucjami UE, analiza kanałów wpływu tj. w jaki sposób podmioty państwowe i niepaństwowe wpływają na siłę wzajemnej interakcji. Ponadto w szeregu badań oceniono czynniki wpływające na wspólne próby wpłynięcia na porządek publiczny w ramach systemu instytucjonalnego Unii Europejskiej czy poszczególnych państw (e.g. Brunell, 2005; De Bruycker, 2016; Fraussen, Halpin, 2018; Heaney, 2010; Klüver, 2018; Marshall, 2015; Otjes, Rasmussen, 2017; Wessels, 2004; Wonka, 2017). Warto jednak zaznaczyć, że tematyka racji stanu została już wcześniej poruszona w krajowej literaturze m.in. w artykule Klaudii Kałużnej i Remigiusza Rosickiego w publikacji $O$ interesie narodowym i racji stanu - rozważania teoretyczne (Kałużna, Rosicki, 2013). Należy jednak podkreślić, że artykuł głównie dotyczy sfery teoretycznej związanej $\mathrm{z}$ racją stanu i jej definiowaniem, zaś nie zawiera analiz związanych z lobbingiem na rzecz polskiej racji stanu i realizacją jej celów, które są głównymi obszarami badawczymi w tym artykule. Podobnie ma to miejsce w przypadku innych publikacji jak np. pod red. Szymona Hatłasa Polska racja stanu, w ramach której nie jest analizowana działalność lobbingowa prowadzona przez aktorów niepaństwowych na rzecz polskiej racji stanu (Hatłas, 2010).

W związku z powyższym głównym problemem badawczym niniejszej analizy jest weryfikacja skuteczności realizacji polskiej racji stanu oraz lobbingu aktorów niepaństwowych na rzecz polskich interesów. Uwzględniając powyższy deficyt badawczy dotyczący analizy lobbingu na rzecz polskiej racji stanu należy postawić kluczowe pytanie badawcze czym jest polska racja stanu (interes narodowy)? i w jaki sposób jest realizowana? Wspomniane kluczowe pytanie badawcze wymaga zarówno wyeksponowania analitycznych i merytorycznych odpowiedzi, ale także konkretnej konceptualizacji pojęciowej nomenklatury interesu narodowego jako terminu. Analizą dotyczącą zdefiniowania interesu narodowego zajmują się politolodzy, prawnicy, historycy, europeiści, ekonomiści czy naukowcy zajmujący się teorią stosunków międzynarodowych. Uwzględniając powyższe pytanie dotyczące zilustrowania polskiej racji stanu (zdefiniowania interesu narodowego) możemy przyjąć następującą definicję interesu narodowego: „...ogólne, długookresowe i kontynuowane cele funkcjonalne w stosunku do celu ostatecznego, któremu służy państwo, naród i władza" (Lerche, Said, 1963, s. 6). Ponadto należy podkreślić, że podobnie jak w przypadku innych państw europejskich polskie interesy narodowe mają charakter długookresowy i funkcjonalny. Interesy Polski dotyczą różnorodnych obszarów związanych z kwestiami polityki gospodarczej (np. pozyskiwania jak największej liczby środków na cele związane z rozwojem obszarów mniej rozwiniętych - polityka spójności) czy kwestiami związanymi $z$ bezpieczeństwem energetycznym lub aspektami militarnymi. Ponadto interes narodowy powinien charakteryzować się następującymi cechami:

- ponadpartyjnością (realizacja celów powinna się odbywać ponad podziałami partyjnymi);

- celowością (zaplanowanych celów skonfrontowanych z politykami krajowymi); 
- długofalowością (zaplanowanych celów aż do osiągnięcia zakładanych rezultatów);

- temporalnością (realizacja w zamierzonym czasie);

- synergicznością (w ramach wybranych polityk).

Uwzględniając realizację polskiego interesu narodowego realizowanego przez poszczególnych aktorów niepaństwowych oraz w oparciu o paradygmat teorii neofunkcjonalnej, można postawić następującą hipotezę, że polska racja stanu jest niewystarczająco realizowana na poziomie europejskim oraz nie wszystkie aspekty dotyczące realizacji polskich interesów są uwzględniane w procesie decyzyjnym Unii Europejskiej, ze względu na brak dostatecznej aktywności pracowników poszczególnych grup interesu i organów Unii Europejskiej, niedobór umotywowanych podejmowanych działań lobbingowych przez poszczególnych aktorów niepaństwowych oraz brak nawiązywania strategicznych koalicji mających wpływ na osiąganie zakładanych celów (np. wdrożenia aktów prawnych). Zmiennymi zależnymi mającymi wpływ na realizację polskiej racji stanu będą: zmiana preferencji społeczeństwa, podejście rządzących do preferencji określonych grup społecznych, wyznaczenie nowych strategii przez Unię Europejską. Zmiennymi niezależnymi mającymi wpływ na realizację polskiej racji stanu będą: sytuacje nadzwyczajne i nieprzewidywalne (stany wyjątkowe np. kryzysy gospodarcze czy pandemie), które wpływają na preferencje społeczeństwa, sytuacje kryzysowe, kadencyjność poszczególnych instytucji, organów i decydentów. Ponadto osiąganie zakładanych rezultatów zależy także od zaangażowania m.in. polskich przedstawicieli pracujących $w$ instytucjach i organach UE (niezależnie od sympatii partyjnych) oraz od silnego lobbingu wykorzystującego kanały narodowe (np. wpływ na członków Rady UE). Taka sytuacja ma znaczące konsekwencje na wywieranie wpływu, reprezentację i obronę polskiej racji stanu na poziomie europejskim. Adekwatną metodą badawczą zastosowaną w niniejszym badaniu będzie metoda systemowa, która umożliwia badanie aktorów niepaństwowych lobbujących na rzecz polskiej racji stanu funkcjonujących w ramach systemu instytucjonalnego. Pomocniczą będzie zaś metoda komparatywna, która posłuży do weryfikacji celów realizowanych przez Unię Europejską i Polskę. Ponadto metoda porównawcza posłuży także do zestawienia działań lobbingowych na przestrzeni ostatniej dekady XXI wieku podejmowanych przez aktorów niepaństwowych promujących polską rację stanu na poziomie europejskim. Ważkim także elementem analizy porównawczej jest ocena forsowania polskich interesów na poziomie unijnym w zakresie ich realizacji i lobbingu, a także egzemplifikacja ich priorytetów i promowanie zakładanych interesów na poziomie Unii Europejskiej.

Wspomniana wyżej teoria neofunkcjonalizmu stanowi podstawę analizy podmiotów niepaństwowych funkcjonujących w systemie instytucjonalnym Unii Europejskiej (Rosamond, 2000, s. 50; Kurczewska, 2008, s. 8). Jak podkreślają Arne Niemann i Philippe Schmitter, neofunkcjonalizm wyróżnia się na tle innych teorii badawczych w dziedzinie nauk społecznych z kilku powodów: zarówno pod względem wyrafinowania, ambicji i aspektów badawczych, jak i ze względu na szeroko zakrojoną krytykę w środowisku naukowym (Niemann, Schmitter, 2009, s. 45). Do lat dziewięćdziesiątych zwolennicy neofunkcjonalizmu twierdzili, że proces integracji europejskiej na poziomie ponadnarodowym i poszerzenie kompetencji władz były wynikiem długie- 
go etapu współpracy gospodarczej. Argumentowali także, że współpraca w jednym obszarze sprawia, że współpraca w obszarach powiązanych z nim jest nieunikniona (Kurczewska, 2011, s. 25). Haas nazwał taki rodzaj współpracy mechanizmem przejściowym, który można wyjaśnić jako formułę ciągłej ekspansji, przy czym głównymi podmiotami uczestniczącymi w procesach integracyjnych w Unii Europejskiej są jej instytucje, elity (propagujące np. polską rację stanu) i analizowani aktorzy niepaństwowi. Niektóre z podstawowych tez wysuniętych przez neofunkcjonalistów wskazują, że proces integracji jest wynikiem interakcji między podmiotami niepaństwowymi, partiami politycznymi, instytucjami transnarodowymi a rządami państw członkowskich (Konopacki, 1998, s. 107). Teoria neofunkcjonalna wskazuje, że podmioty niepaństwowe pełnią istotną funkcję w kształtowaniu procesu integracji oraz w jednoczącej się Europie i tym samym mają istotny wpływ na realizowanie interesów poszczególnych państw członkowskich UE (Kurczewska, 2011, s. 26). Według Haasa teoria neofunkcjonalna zakłada, że państwo funkcjonuje jak zespół, w którym istnieją różne interesy reprezentowane przez określonych aktorów niepaństwowych (Haas, 1964, s. 37), podczas gdy głównym celem podmiotów niepaństwowych i elit jest artykułowanie partykularnych interesów i dążenie do ich realizacji poprzez działalność polityczną (Haas, 1964, s. 230).

Pomimo aspektów zaznaczonych w hipotezie badawczej mających negatywny obraz wskazujący braki dostatecznej skuteczności reprezentacji polskich interesów na poziomie europejskim postaram się zaprezentować także podejmowane pozytywne działania lobbingowe realizujące polską rację stanu (polski interes narodowy). Jednym z elementarnych obszarów dla Polski jest kwestia związana z polityką europejską uwzględniającą priorytety polskich interesów w UE. Ponadto w artykule zajmę się analizą obszarów związanych z Unią Europejską, które zostały uwzględnione w ramach polityki spójności 2014-2020 oraz w priorytetach polskiej polityki zagranicznej 2017-2021 (Ministerstwo Spraw Zagranicznych Rzeczpospolitej Polskiej, 2017, s. 5).

\section{Priorytety polskich interesów w polityce Unii Europejskiej}

Polska polityka na poziomie europejskim jest realizowana w znacznym stopniu w oparciu o realizację celów, które wpływają na modernizację kraju, uwzględniając postęp gospodarczy, rozwój infrastrukturalny czy postęp technologiczny. Takie zapisy zostały zawarte w ramach polityki spójności realizowanej w latach 2014-2020 oraz doprecyzowane w priorytetach polskiej polityki europejskiej 2017-2021 (Ministerstwo Spraw Zagranicznych Rzeczpospolitej Polskiej, 2017, s. 5). W dokumentach zwrócono szczególną uwagę na kwestie modernizacyjne kraju, co należy uznać za słuszne podejście polskiej strony dotyczące rozwoju kraju w stosunku do pozostałych państw UE. Takie podejmowane działania uwzględniające wykorzystanie środków UE (funduszy europejskich a w szczególności unijnych²) ma na celu wyrównanie dysproporcji

${ }^{2}$ Fundusze europejskie są to środki pochodzące nie tylko z Unii Europejskiej (UE), ale także z takich państw jak Norwegia, Islandia czy Liechtenstein - państw nienależących do UE, ale należących do Europejskiego Obszaru Gospodarczego (EOG), natomiast fundusze unijne są to środki pochodzące tylko z UE. 
pomiędzy krajami zachodnimi UE a pozostałymi z Europy Środkowo-Wschodniej, a w szczególności pomiędzy regionami mniej i bardziej rozwiniętymi pod względem gospodarczym. Działanie to przyczyni się do umocnienia pozycji Polski w różnych obszarach na poziomie europejskim i międzynarodowym (obszarze nauki, gospodarczym czy w społecznym).

Uwzględniając priorytety i interesy rozwoju Polski związane z realizacją polskiej racji stanu na poziomie europejskim w latach 2017-2021 Polska wyznaczyła cele do osiągnięcia w następujących obszarach (Ministerstwo Spraw Zagranicznych Rzeczpospolitej Polskiej, 2017, s. 5):

- bezpieczeństwa - działania służące rozbudowie własnych zdolności obronnych, wzmocnieniu potencjału relacji sojuszniczych Polski w ramach NATO i UE;

- rozwoju - aktywność międzynarodowa służąca rozwojowi gospodarczemu i społecznemu;

- autorytetu międzynarodowego - czynnik umożliwiający kształtowanie pozytywnego wizerunku Polski i umacnianie jej wiarygodności w skali europejskiej i globalnej.

\section{Bezpieczeństwo}

Bezpieczeństwo Polski uległo poważnemu pogorszeniu w wyniku aneksji Krymu przez Rosję co w efekcie miało wpływ na rozwój silnego konfliktu we wschodniej części Ukrainy (Ministerstwo Spraw Zagranicznych Rzeczpospolitej Polskiej, 2017, s. 6). Takie działania jak wojna czy agresja przeciw sąsiednim suwerennym państwom, pogwałcenie integralności terytorialnej miały wpływ na wprowadzanie strategicznych zmian w priorytetach polskiej racji stanu w ostatnich latach, w której kluczowym elementem jest zachowanie bezpieczeństwa kraju i stabilnych relacji z sąsiadującymi państwami zarówno z Unii Europejskiej, jak i spoza jej struktur. Jak zostało wskazane w dokumencie zagrożenie militarne, a tym samym brak dostatniego bezpieczeństwa państwa wskazuje na obraz, który był widoczny w okresie II wojny światowej (Ministerstwo Spraw Zagranicznych Rzeczpospolitej Polskiej, 2017, s. 6).

W związku z powyższym kluczową polską racją stanu jest zachowanie bezpieczeństwa narodowego opartego na fundamentalnych zasadach, które są także propagowane przez Unię Europejską. Ponadto polską racją stanu będzie zapewnienie bezpieczeństwa wymagającego podjęcia jednoczesnych działań w trzech, uzupełniających się wymiarach (Ministerstwo Spraw Zagranicznych Rzeczpospolitej Polskiej, 2017, s. 7):

- sojuszniczym - polegającym na wzmocnieniu wiarygodności NATO i potencjału UE oraz zachowaniu bliskich stosunków z USA;

- regionalnym - zorientowanym na zacieśnianie współpracy z państwami naszego regionu, zwłaszcza z Rumunią, Grupą Wyszehradzką, państwami bałtyckimi i nordyckimi, a także na aktywną politykę wschodnią;

- krajowym - mającym na celu istotne wzmocnienie własnych zdolności obronnych. W interesie Polski leży, by w ramach Wspólnej Polityki Bezpieczeństwa i Obrony Unia Europejska zmierzała w stronę osiągnięcia zdolności do działań autonomicz- 
nych, przy jednoczesnym utrzymaniu komplementarności w stosunku do Sojuszu Północnoatlantyckiego (NATO). Wskazane postulaty w ramach deklaracji warszawskiej UE-NATO, w której to głównym celem Polski jest aktywne wspieranie planu działań na rzecz wzmocnienia współpracy obydwu organizacji w odniesieniu do zagrożeń hybrydowych, poprawy bezpieczeństwa w cyberprzestrzeni, w tym także wzmocnienia militarnego partnerów w sąsiedztwie wschodnim i południowym. Sprzyjać temu powinny również działania zmierzające do wzmocnienia europejskich zdolności obronnych, w tym rozwoju europejskiego przemysłu obronnego uwarunkowanego i wynikającego z realnej oceny stanu bezpieczeństwa w Unii Europejskiej. Inicjatywy te powinny być zrównoważone i transparentne oraz uwzględniać interesy wszystkich państw członkowskich UE, w tym także Polski (Ministerstwo Spraw Zagranicznych Rzeczpospolitej Polskiej, 2017, s. 8).

\section{Rozwój}

W ramach rozwoju społeczno-gospodarczego Polski i ochrony polskiej racji stanu jest zapewnienie możliwości wzrostu dobrobytu jej mieszkańców oraz umocnienie pozycji gospodarczej w skali globalnej, co należy do najważniejszych celów polskiej polityki zagranicznej. Głównym założeniem w tej sferze będzie zabezpieczenie odpowiedniego wsparcia zagranicznego dla realizacji Strategii na rzecz Odpowiedzialnego Rozwoju do roku 2020 (z perspektywą do 2030 r.) w ramach polityki spójności Unii Europejskiej realizowanej w Polsce w latach 2014-2020 i kontynuowanej w kolejnej perspektywie finansowej 2021-2027. Istotną kwestią w ramach promowania i ochrony polskiej racji stanu jest także realizacja Planu Odpowiedzialnego Rozwoju w jego pięciu podstawowych filarach: reindustrializacji, rozwoju innowacyjności, zapewnienia kapitału dla inwestycji, ekspansji zagranicznej oraz rozwoju społecznego i regionalnego (Ministerstwo Spraw Zagranicznych Rzeczpospolitej Polskiej, 2017, s. 13). Należy podkreślić, że założenia te wpisują się w realizację polityki spójności w Polsce.

Ponadto dla rozwoju Polski fundamentalne znaczenie będzie miał kierunek ewolucji Unii Europejskiej. Dotyczy to przede wszystkim przyszłości strefy euro, polityki spójności, Wspólnej Polityki Rolnej, polityki energetycznej i klimatycznej oraz planu utworzenia jednolitego europejskiego obszaru transportowego. Istotnym zagrożeniem dla funkcjonowania rynku wewnętrznego UE są ukryte oraz pośrednie mechanizmy protekcjonistyczne $\mathrm{w}$ postaci prawodawstwa socjalnego oraz praktyk, które prowadzą do fragmentacji rynku wewnętrznego i ograniczenia konkurencyjności, a to z kolei ma kluczowe znaczenie dla przedsiębiorców szczególnie z sektora małych i średnich przedsiębiorstw (MŚP). Kluczową kwestią uwzględniającą polską rację stanu będzie utrzymanie przez Unię Europejską jedności i minimalizowanie podziałów wewnętrznych na tle zarządzania gospodarczego. Integralność rynku we-wnętrznego Unii Europejskiej jest ważnym warunkiem rozwoju gospodarczego Europy i Polski. Istotnym celem Polski w tym obszarze jest wpływanie na jego rozwój, szczególnie w kwestiach niezrealizowanych jak np. w obszarze świadczenia usług czy w ramach projektów innowacyjnych - rynek cyfrowy (Ministerstwo Spraw Zagranicznych Rzeczpospolitej Polskiej, 2017, s. 13). 


\section{Autorytet międzynarodowy}

Jednym z głównych przesłań związanych z realizacją polskiej racji stanu jest realizm polityczny, dążenie do szukania rozwiązań pragmatycznych. Z punktu widzenia lobbingu na rzecz autorytetu międzynarodowego, status państwa (Polski) na arenie europejskiej nie opiera się wyłącznie na zdolnościach militarnych czy potencjale gospodarczym. Obecność wartości reprezentowanych przez poszczególne państwa członkowskie w polityce europejskiej ściśle łączy się z wiarygodnością jej uczestników. Polska, chcąc oddziaływać na ewolucję swojego, szeroko rozumianego europejskiego otoczenia, musi występować w charakterze odpowiedzialnego uczestnika polityki europejskiej. Takie działania zakładają przede wszystkim realizację zobowiązań europejskich (w tym także zobowiązań traktatowych). Podejmowane przez Polskę inicjatywy dotyczą redukcji ubóstwa, niwelowania różnic rozwojowych, czy pobudzania przedsiębiorczości w kraju. Tym samym przyczyniają się do poprawy bezpieczeństwa Polski i jej obywateli. Szczególnego znaczenia nabierają działania lobbingowe Polski na rzecz rozwoju technologii komunikacyjnych i rewolucji cyfrowej. W celu lobbowania na rzecz polskiej racji stanu wobec poprawy oraz utrzymania odpowiedniego wizerunku Polski za granicą podejmowane działania przez aktorów niepaństwowych powinny być kluczowe, a ich zakres zakorzeniony w tradycji i jednocześnie otwarty na nowoczesność w jej najważniejszych obszarach. Promowanie autorytetu przez aktorów niepaństwowych powinno być traktowane jako jeden z elementów strategii polskiej racji stanu, współgrający z celami w sferze bezpieczeństwa i rozwoju gospodarczego (Ministerstwo Spraw Zagranicznych Rzeczpospolitej Polskiej, 2017, s. 21).

Wymienione trzy kluczowe wymiary zawierają priorytety związane z realizacją polskiej racji stanu w Unii Europejskiej. W nawiązaniu do tych zdefiniowanych wymiarów Polska wystosowała określone zadania, które powinny być lobbowane na rzecz obrony polskich interesów w UE. Wyróżnione zadania związane z lobbingiem na rzecz polskiej racji stanu zostały przedstawione $\mathrm{w}$ tabeli 1 .

Tabela 1

Realizowane zadania w ramach polskiej racji stanu w UE w obszarze bezpieczeństwa, rozwoju i autorytetu międzynarodowego

\begin{tabular}{|c|c|}
\hline Obszar & Specyfika zadania w ramach Unii Europejskiej \\
\hline Bezpieczeństwo & $\begin{array}{l}\text { Sojusze: } \\
\text { - } \text { kontynuować działania na rzecz wzmocnienia wschodniej flanki przy jednocze- } \\
\text { snym, solidarnym zaangażowaniu w działania na południu UE, między innymi we } \\
\text { współpracy z Turcją; } \\
\text { - } \text { podejmować działania na rzecz współpracy pomiędzy NATO i UE w ramach de- } \\
\text { klaracji warszawskiej. } \\
\text { Sąsiedztwo: } \\
\text { - } \quad \text { wpierać politykę otwartych drzwi Unii Europejskiej i Sojuszu Północnoatlantyc- } \\
\text { kiego; } \\
\text { - } \text { kontynuować współpracę w dziedzinie wzmacniania flanki wschodniej z państwa- } \\
\text { mi bałtyckimi i Rumunią, zwłaszcza w takich dziedzinach jak Misja Patrolowania } \\
\text { Przestrzeni Powietrznej (Air Policing) i Wzmocniona Wysunięta Obecność (En- } \\
\text { hanced Forward Presence); }\end{array}$ \\
\hline
\end{tabular}




\begin{tabular}{|c|c|}
\hline Obszar & Specyfika zadania w ramach Unii Europejskiej \\
\hline & $\begin{array}{l}\text { - } \text { utrzymać współpracę z Czechami, Słowacją i Węgrami w ramach Wyszehradzkiej } \\
\text { Grupy Bojowej; } \\
\text { - } \text { wzmacniać więzi infrastrukturalne pomiędzy państwami w regionie bałtyckim } \\
\text { i Europie Środkowej, w tym państw położonych pomiędzy Morzem Bałtyckim, } \\
\text { Morzem Czarnym oraz Morzem Adriatyckim; } \\
\text { - } \text { kontynuować działania na rzecz zacieśniania współpracy przemysłów obronnych } \\
\text { krajów wyszehradzkich, a także współpracy polskiego sektora zbrojeniowego } \\
\text { z partnerami skandynawskimi; } \\
\text { - pogłębiać współpracę w ramach Trójkąta Weimarskiego. }\end{array}$ \\
\hline & $\begin{array}{l}\text { Sila: } \\
-\quad \text { wykorzystać proces modernizacji sił zbrojnych w celu transferu do Polski nowo- } \\
\text { czesnych technologii; } \\
-\quad \text { wspierać międzynarodową obecność polskiego przemysłu obronnego, w tym jego } \\
\text { uczestnictwo w inicjatywach podejmowanych w ramach UE i NATO. }\end{array}$ \\
\hline \multirow[t]{2}{*}{ Rozwój } & $\begin{array}{l}\text { Europa: } \\
\text { - } \text { zapewnić realizację interesów polskich podczas negocjacji wieloletnich ram finan- } \\
\text { sowych UE na lata } 2021-2027 \text {, ze szczególnym uwzględnieniem polityki spójno- } \\
\text { ści i Wspólnej Polityki Rolnej. } \\
\text { - } \text { podtrzymywać stanowisko, zgodnie z modelem opartym na czterech fundamen- } \\
\text { talnych wolnościach: swobodzie przemieszczania się ludzi, kapitału, towarów } \\
\text { i usług - oraz na poszanowaniu zasady pomocniczości w ramach Unii Europej- } \\
\text { skiej; } \\
\text { - } \text { doprowadzić do pełnej realizacji zasady swobody przepływu usług, a w odniesie- } \\
\text { niu do rynku cyfrowego również swobody przepływu towarów, a także treści cy- } \\
\text { frowych i danych przy poszanowaniu ochrony prywatności i określeniu wyjątków } \\
\text { wynikających z potrzeby zapewnienia bezpieczeństwa publicznego; } \\
\text { - działać na rzecz utrzymania mobilności pracowniczej na obszarze UE; } \\
\text { - dążyć do powiązania polityki klimatycznej UE z postulatem utrzymania konkuren- } \\
\text { cyjności przez gospodarkę unijną; } \\
\text { - wspierać działania na rzecz stabilizacji strefy euro przy jednoczesnym utrzymaniu } \\
\text { jedności i spójności Unii oraz demokratycznej kontroli wyborców nad systemami } \\
\text { podatkowymi i finansami publicznymi swoich państw; } \\
\text { - utrzymać działania na rzecz wzmocnienia głosu państw środkowoeuropejskich } \\
\text { w Unii Europejskiej; } \\
\text { - zapewnić swobodę kształtowania przez poszczególne państwa członkowskie ko- } \\
\text { generacji energetycznej, polityki energetyczno-klimatycznej i decyzji inwestycyj- } \\
\text { nych z poszanowaniem zasady subsydiarności i neutralności technologicznej w ra- } \\
\text { mach negocjacji związanych z projektami legislacyjnymi wchodzącymi w skład } \\
\text { przedłożonego przez Komisję Europejską pakietu „Czysta energia dla wszystkich } \\
\text { Europejczyków”. }\end{array}$ \\
\hline & $\begin{array}{l}\text { Ekonomia: } \\
\text { - wspierać działania podejmowane w ramach Polskiego Funduszu Rozwoju - two- } \\
\text { rzenie nowoczesnego, skutecznego mechanizmu promocji gospodarczej za grani- } \\
\text { cą, realizującego cele w powiązaniu ze Strategią na rzecz Odpowiedzialnego Roz- } \\
\text { woju do roku } 2020 \text { (z perspektywą do } 2030 \text { r.) oraz Planem Odpowiedzialnego } \\
\text { Rozwoju i zorientowane na wsparcie polskich przedsiębiorstw i ich inicjatyw na } \\
\text { rynkach zagranicznych oraz pozyskiwanie inwestycji i technologii; } \\
\text { - podejmować działania sprzyjające większemu wykorzystaniu przez podmioty } \\
\text { polskie narzędzi wsparcia rozwoju nowoczesnych technologii i innowacyjności, } \\
\text { w tym programu Horizon } 2020 \text {. } \\
\text { - podejmować działania na rzecz włączenia współpracy naukowej do dialogu mię- } \\
\text { dzynarodowego, zwłaszcza w odniesieniu do dziedzin mających znaczenie dla roz- } \\
\text { woju społeczeństwa i gospodarki opartej na wiedzy. }\end{array}$ \\
\hline
\end{tabular}




\begin{tabular}{|c|c|}
\hline Obszar & Specyfika zadania w ramach Unii Europejskiej \\
\hline & $\begin{array}{l}\text { Ekspansja: } \\
-\quad \text { działać na rzecz wzrostu udziału towarów wysoko przetworzonych w strukturze } \\
\text { polskiego eksportu; } \\
-\quad \text { dążyć do zwiększenia wolumenu eksportowego polskich surowców; } \\
-\quad \text { zabiegać o korzystne dla Polski zapisy w negocjowanych przez UE porozumie- } \\
\text { niach handlowych; } \\
-\quad \text { kontynuować realizację inicjatyw infrastrukturalnych obliczonych na wzmocnie- } \\
\text { nie spójności Europy Środkowej, zwłaszcza na osi północ-południe. }\end{array}$ \\
\hline \multirow[t]{3}{*}{$\begin{array}{l}\text { Autorytet mię- } \\
\text { dzynarodowy }\end{array}$} & $\begin{array}{l}\text { Wartości: } \\
\text { - } \quad \text { umacniać w polityce europejskiej znaczenie wartości zapisanych w podstawowych } \\
\text { aktach UE, Rady Europy i OBWE; } \\
\text { - } \text { działać na rzecz odzyskania przez Unię Europejską równowagi pomiędzy zasadą } \\
\text { suwerenności państwowej i prerogatywami instytucji unijnych, a także na rzecz } \\
\text { wzmocnienia transparencji i mandatu demokratycznego unijnych procesów decy- } \\
\text { zyjnych; } \\
\text { - } \\
\text { wspierać działania w odniesieniu do polityki prorodzinnej w szczególności na } \\
\text { gruncie regulacji prawnych; } \\
\text { - } \\
\text { traktować promocję polskości za granicą jako platformę do promocji wartości } \\
\text { obecnych w polskiej historii i kulturze. }\end{array}$ \\
\hline & $\begin{array}{l}\text { Wiarygodność i odpowiedzialność: } \\
\text { - } \text { realizować konsekwentnie zobowiązania wynikające z Agendy Zrównoważonego } \\
\text { Rozwoju 2030 (ONZ) oraz polskiego Programu Współpracy Rozwojowej na lata } \\
\text { 2016-2020; } \\
\text { - } \text { dążyć do zaangażowania krajowego sektora prywatnego w działania z zakresu pol- } \\
\text { skiej współpracy na rzecz rozwoju. }\end{array}$ \\
\hline & $\begin{array}{l}\text { Wizerunek: } \\
\text { - } \quad \text { traktować budowę i obronę dobrego imienia Rzeczypospolitej jako element pro- } \\
\text { mocji politycznej i gospodarczej; } \\
\text { - } \quad \text { wypracować założenia dyplomacji naukowej, promujące polskie osiągnięcia i po- } \\
\text { tencjał naukowy Polski; } \\
\text { - } \\
\quad \text { wzmacniać międzynarodowy autorytet Polski poprzez aktywną politykę stypen- } \\
\quad \text { dialną i budowanie trwałych relacji z absolwentami z zagranicy. }\end{array}$ \\
\hline
\end{tabular}

Źródło: Opracowanie własne na podstawie Ministerstwo Spraw Zagranicznych Rzeczpospolitej Polskiej, Strategia Polskiej Polityki Zagranicznej 2017-2021, s. 6-27, 20.06.2020.

Dokonując analizy realizacji wyznaczonych powyższych zadań poprzez poszczególnych aktorów niepaństwowych należy podsumować i wymienić kluczowe dla Polski obszary zainteresowań. Uwzględniając powyższe do najbardziej istotnych obszarów, które realizują polskie interesy należą: środowisko, innowacje, finanse, bezpieczeństwo, energetyka, rybołówstwo czy sprawy związane z rolnictwem oraz przemysłem chemicznym. Należy podkreślić, że te obszary są związane ze ścisłym i ukierunkowanym rozwojem kraju poprzez wykorzystanie możliwości dotacyjnych pochodzących choćby z funduszy UE w latach 2014-2020 i kontynuowane w nowej perspektywie finansowej Unii Europejskiej 2021-2027. Jednocześnie wpisują się one w istotne obszary polityk promowanych przez Unię Europejską (takich jak środowisko, energetyka, innowacyjność), co podkreśla zbieżność promocji określonych polskich interesów w tych obszarach $\mathrm{z}$ kierunkiem rozwoju polityk europejskich. 


\section{Realizacja polskiego interesu na poziomie Unii Europejskiej}

Do kluczowych aktorów niepaństwowych dbających o interesy Polski jest nowo powstały podmiot w 2019 roku Business \& Science Poland w Brukseli - BSP (Rząsa, 2019; Pogorzelski, 2019). Premier Mateusz Morawiecki otworzył w Brukseli biuro podmiotu, które ma stanowić centrum lobbingowe dla polskiego biznesu i obrony polskiej racji stanu w Unii Europejskiej (Pogorzelski, 2019). Business \& Science Poland (BSP) jest Związkiem Pracodawców zarejestrowanych w Polsce. Główną misją BSP jest wsparcie polskich przedsiębiorców i nauki w efektywnym formowaniu europejskiej agendy, a także w programowaniu i wydatkowaniu środków unijnych na naukę, badania i rozwój oraz inwestycje. Jak podkreślają zarządcy, Business \& Science Poland członkami są polskie podmioty, które potrafią definiować swoje interesy długoterminowo i chcą skutecznie zarząazać ryzykiem regulacyjnym, a ponadto mają interesy skorelowane z priorytetami polskiej racji stanu w UE. Na poziomie europejskim Business \& Science Poland wspiera także organizacje branżowe zrzeszające polskich przedsiębiorców, w tym z sektora MŚP (Business \& Science Poland, 2020). Jak wynika z raportu dotyczącego pierwszego roku aktywności w Brukseli, BSP silnie angażuje się w podejmowane działania lobbingowe na rzecz wpływu na proces decyzyjny wobec zdefiniowanych kluczowych polskich interesów. Jak zostało podkreślone w raporcie, organizacja lobbingowa Business \& Science Poland wzięła udział w dziesięciu konsultacjach publicznych (Komisji Europejskiej - Komisji) oraz sformułowała jedenaście stanowisk eksperckich wobec tematów związanych z bieżącą agendą Unii Europejskiej (Business \& Science Poland, 2020, Raport podsumowujacy 1. rok działalności, s. 14). Do kluczowych sukcesów BSP zalicza trzy najbardziej istotne $\mathrm{z}$ punktu widzenia obrony interesów $\mathrm{w}$ ramach polskiej racji stanu: budowanie sojuszy w ramach projektu dot. wytycznych KE ws. pomocy państwa w ramach ETS [Emissions Trading System - EU ETS ${ }^{3}$, (Komisja Europejska, 2020)], aktywizacja BSP związana z działaniem dotyczącym propozycji odnośnie unijnego „węglowego mechanizmu granicznego" (Business \& Science Poland, 2020, Raport podsumowujący 1. rok działalności, s. 16) oraz aktywność BSP związana ze wsparciem działań sektorowych stanowiska Unii Europejskiej nt. globalnego systemu handlu emisjami w lotnictwie [CORSIA, (Business \& Science Poland, 2020, Raport podsumowujacy 1. rok działalności, s. 17)].

W ramach pierwszej aktywności BSP włączyło się w proces formułowania nowych wytycznych dotyczących rekompensat za zwiększone koszty energii elektrycznej wynikające z systemu ETS. Regulacje te, zezwalające na stosowanie mechanizmu kompensacji wobec firm, których produkcja związana jest z wysoką konsumpcją energii elektrycznej, zostaną dostosowane do nowego systemu handlu uprawnieniami do emisji na lata 2021-2030. Celem Komisji Europejskiej jest wprowadzenie ograniczenia liczby sektorów uprawnionych do korzystania z pomocy państwa. Lobbing w tej sprawie został poczyniony przez BSP, co pozwoliło na włączenie do działania

${ }^{3}$ ETS - unijny system handlu uprawnieniami do emisji (EU ETS) jest kluczowym elementem polityki UE na rzecz walki ze zmianą klimatu oraz jej podstawowym narzędziem służącym do zmniejszania emisji gazów cieplarnianych w sposób opłacalny. Jest to pierwszy i dotychczas największy na świecie rynek uprawnień do emisji dwutlenku węgla. 
organizacje sektorowe, członków tej organizacji. Poparcie w niniejszej sprawie BSP uzyskało ponad podziałami m.in. od piętnastu polskich deputowanych do PE z trzech komisji parlamentarnych i wszystkich grup politycznych, którzy wystosowali list do Vice-Przewodniczących Komisji Europejskiej podkreślając, że system rekompensat ma na celu przeciwdziałanie ryzyku przenoszenia się firm o wysokiej konsumpcji energii elektrycznej poza UE oraz minimalizowanie zakłóceń w konkurencji na rynku wewnętrznym (Business \& Science Poland, 2020, Raport podsumowujacy 1. rok dziatalności, s. 15).

Kolejną słuszną inicjatywą mającą na celu obronę polskiego interesu była aktywizacja BSP związana z działaniem dotyczącym propozycji odnośnie unijnego ,węglowego mechanizmu granicznego". BSP jako jedna z pierwszych organizacji w Brukseli wypracowała kompleksowe stanowisko w tej sprawie. Jak podkreśla BSP udało się jej uwzględnić techniczne i koncepcyjne wyzwania, perspektywę partnerów zagranicznych oraz zgodności mechanizmu z WTO. Dzięki zastosowaniu lobbingu ofensywnego interesy członków BSP mogą być brane pod uwagę na etapie tworzenia projektu aktu prawnego, a także co jest istotne z punktu widzenia obrony interesów członków BSP przed otwarciem konsultacji KE (Business \& Science Poland, 2020, Raport podsumowujący 1. rok działalności, s. 16).

Trzecią aktywnością mającą na celu obronę polskich interesów była aktywność BSP związana ze wsparciem działań sektorowych stanowiska Unii Europejskiej nt. globalnego systemu handlu emisjami w lotnictwie (CORSIA). BSP podjęło działania wspierające sektor lotniczy w sprawie wynikającej z kryzysu wywołanego przez COVID-19. Wstrzymanie ruchu lotniczego spowodowało znaczne zmniejszenie liczby emisji lotniczych w 2020 roku. Uwzględnienie średnich emisji za lata 2019-2020 jako okresu referencyjnego w systemie CORSIA byłoby nieproporcjonalnie niskie pod względem wartości (ze względu na COVID-19), zaś linie lotnicze musiałyby ponosić nieuzasadnione wysokie koszty związane z kompensacją za emisje. W związku z powyższym, BSP włączyło się w kampanię lobbingową w imieniu sektora lotniczego i w kwietniu 2020 roku przedstawiło postulat dotyczący zmiany okresu referencyjnego w stanowisku skierowanym do Komisji Europejskiej na temat priorytetów wychodzenia z kryzysu. Taka aktywność BSP związana z lobbingiem na rzecz sektora lotniczego wzmocniła także przekaz innych organizacji branżowych (lobbing koalicyjny), co miało wpływ na podjęcie decyzji przez dwudziestu siedmiu ministrów transportu państw członkowskich w ramach Rady Unii Europejskiej, zgodnie z postulatami operatorów lotniczych (Business \& Science Poland, 2020, Raport podsumowujący 1. rok działalności, s. 17).

Należy jednak podkreślić, że takie podejmowane skuteczne działania przez Business \& Science Poland mają charakter bardziej marginalny aniżeli powszechny. W Brukseli powstaje ponad 75\% prawa unijnego, które jest transponowane do prawa krajowego poszczególnych państw członkowskich Unii Europejskiej (Rząsa, 2019). To świadczy tylko o tym jak ważnym centrum decyzyjnym jest Unia Europejska, która pośrednio ma wpływ na życie obywateli we wszystkich dwudziestu siedmiu państwach członkowskich. Dowodem tej marginalności są chociażby dotychczasowe prowadzone wybrane kampanie lobbingowe (lub ich deficyt w ramach określonych spraw). Dobrym przykładem zaniedbania lobbingu w ramach polskiej racji 
stanu było podjęte działanie w 2018 roku na rzecz rewizji dyrektywy Clean Vehicles Directive - CVD (Dyrektywa Parlamentu Europejskiego i Rady, 2019, s. 5-12). Zaniedbanie lobbingu na rzecz polskiej racji stanu nastąpiło w drugiej dekadzie 2018 roku, kiedy to miały się zakończyć unijne prace nad sprawozdaniem rewizji dyrektywy CVD. Paradoks polegał na tym, że polscy przedstawiciele w pierwszej dekadzie 2018 roku (kiedy nastąpił kulminacyjny moment lobbingu na rzecz nowelizacji wspomnianej dyrektywy) uczestniczyli w tym samym czasie w kongresie o tej samej tematyce w Warszawie, zamiast być aktywnym na forum unijnym, w którym to nawet opuszczający Unię Europejską brytyjscy lobbyści byli obecni w Brukseli (Baca-Pogorzelska, Cedro, 2018). Interesującym jest fakt, że polscy przedstawiciele twierdzili, że to nie było zaniechanie, ponieważ rozwiązanie zaproponowane przez KE było zgodne z polską racją stanu. Może i ta ocena wydaje się słuszna ze strony polskiego rządu, natomiast propagowanie takiej postawy wydaje się nieracjonalne, ponieważ brak ciągłej aktywności ma lub może mieć wpływ na końcowe unijne rozwiązania legislacyjne. Polscy lobbyści w tym przypadku powinni być aktywni do końca procesu legislacyjnego, zaś jego niedopilnowanie mogłoby skutkować poważniejszymi konsekwencjami mającymi wpływ na realizację polskich interesów.

Kluczowe zobrazowane powyżej zadania związane są z szeroko definiowanym promowaniem i obroną polskich interesów na poziomie europejskim. Ponadto te cele mają charakter skonkretyzowany i racjonalny, zaś ich założenia są istotne z punktu widzenia rozwoju Polski w Unii Europejskiej.

\section{Wnioski de lege ferenda}

Wnioski dla Polski dotyczące odpowiednio prowadzonego skutecznego lobbingu są trudne do przewidzenia. Z jednej strony, Polska powinna dbać o polską rację stanu - swoje interesy, z drugiej strony, realizacja interesów Unii Europejskiej ma charakter wypadkowy, który powinien uwzględniać interesy wszystkich państw członkowskich. Ważnym aspektem jest jednak także dbanie o interesy poszczególnych państw UE (w tym Polski). Zatem dlaczego realizacja polskich interesów na poziomie europejskim ma charakter bardziej temporalny ad-hoc niż stały konsekwentny? Uwzględniając hipotezę przedstawioną na początku artykułu, należy podkreślić, że choć jest ona pesymistyczna, to należy się z nią zgodzić. Za takim stanem rzeczy przemawia deficyt aktywności polskich stałych pracowników w ramach poszczególnych instytucji i organów UE oraz brak należytego zaangażowania ze strony poszczególnych aktorów niepaństwowych (grup interesu). Należy jednak podkreślić, że aktorzy niepaństwowi mają za zadanie lobbować na rzecz swoich członków (w ich interesie), a ich działania lobbingowe nie zawsze pokrywają się z polską racją stanu, wręcz można by rzec, że często nie są spójne, bo lobbing głównie polega na obronie interesów członków, a nie poszczególnych państw. Drugim ważnym elementem jest brak dostatecznej koordynacji działań na forum międzynarodowym tzn. deficyt podejmowanych działań sojuszniczych. Sojusze są zawiązywane bardzo rzadko, co ma wpływ na to, że polska racja stanu nie może być w pełni zrealizowana poza kilkoma analizowanymi interesami realizowanymi w ramach poszczególnych aktorów niepaństwowych, polski interes na 
poziomie europejskim jest niedostatecznie reprezentowany. Co zatem można zrobić, aby podnieść skuteczność takich działań?

Należy, po pierwsze, skoordynować działania, które będą funkcjonowały ponad podziałami, bez względu na przynależności i sympatie partyjne wewnątrz kraju (przykład utworzenia Business \& Science Poland). Nowa polska grupa lobbingowa może mieć większy wpływ na podejmowane decyzje w Unii Europejskiej, a co się z tym wiąże także na silniejszą obronę polskiej racji stanu i kluczowych dla Polski interesów w wymiarze zarówno gospodarczym, jak i naukowym. Nowy ośrodek może być także receptą na słabą skuteczność obrony polskich interesów związanych zarówno z polską racją stanu, jak i ze sferą prywatną. Po drugie - strategie w ramach poszczególnych priorytetów (obszarów) powinny być klarowne, a cele jasno sprecyzowane. Po trzecie - działania nie powinny być działaniami ad-hoc, lecz powinny być stałe. Dobrym rozwiązaniem byłoby także zwiększenie liczby pracowników w ramach organów i instytucji Unii Europejskiej, w szczególności polskich ekspertów z danej dziedziny. Ważkim elementem byłaby także możliwość ograniczania liczby założonych celów do osiągniecia przez stronę Polską, a także prowadzenie przemyślanych i racjonalnych kampanii lobbingowych. Warto także podejmować współpracę z innymi państwami mającymi podobne priorytety na poszczególne zagadnienia tzn. prowadzić lobbing koalicyjny. Zatem należy podkreślić, że wspomniani w powyższej analizie aktorzy niepaństwowi mają ograniczony wpływ, ze względu na deficytową reprezentację na forum europejskim, na realizację polskiej racji stanu i tym samym nie mają kluczowego wpływu, który przyczyniłby się do realizacji polskiego interesu narodowego. Konkluzja jest dość negatywna dla strony polskiej, jednakże może przyczyni się do większej ekspansywności i realizacji polskiej racji stanu, a także do postrzegania Polski jako silnego merytorycznego partnera, dbającego o swoje interesy poprzez poszczególne działania lobbingowe prowadzone przez aktorów niepaństwowych w Unii Europejskiej.

\section{Bibliografia}

Baca-Pogorzelska K., Cedro M. (2018), Dlaczego Polacy nie umieja lobbować? Nie potrafimy pilnować swoich interesów w Brukseli, 13.04.2018, „Dziennik.pl, Gazeta Prawna”, https://gospodarka.dziennik.pl/news/artykuly/572556,lobbing-polacy-bruksela-interesy-cvd-zachod. html, 12.07.2020.

Brunell T. L. (2005), The relationship between political parties and interest groups: Explaining patterns of PAC contributions to candidates for congress, „Political Research Quarterly”, 58(4), s. 681-688, DOI: 10.2307/3595653.

Business \& Science Poland (2020), Głos polskiego biznesu i nauki w Brukseli, https://zpbsp.com/pl/ home/, 12.07.2020.

Business \& Science Poland (2020), Raport podsumowujacy 1. rok działalności, 21.06.2020, https:// zpbsp.com/pl/bspnews/raport-z-1-roku-dzialalnosci-bsp/, 12.07.2020.

De Bruycker I. (2016), Power and position: Which EU party groups do lobbyists prioritize and why?, „Party Politics”, 22(4), s. 552-562, DOI: 10.1177/1354068816642803.

Dyrektywa Parlamentu Europejskiego i Rady (2009), 2009/33/WE z dnia 23 kwietnia 2009 r. w sprawie promowania ekologicznie czystych i energooszczędnych pojazdów transportu drogowe- 
go (Tekst mający znaczenie dla EOG), Dz. U. L 120 z 15.5.2009, wersja skonsolidowana 1.08.2019, https://eur-lex.europa.eu/legal-content/PL/TXT/PDF/?uri=CELEX:02009L0033$-20190801 \&$ from $=$ PL, 12.07.2020.

Fraussen B., Halpin D. (2018), Political parties and interest organizations at the crossroads: Perspectives on the transformation of political organizations, „Political Studies Review”, 16(1), s. 25-37, DOI: 10.1177/1478929916644868.

Hatłas Sz. (red.) (2010), Polska racja stanu, tom 11, Studia i Analizy Collegium Civitas, Warszawa. Heaney M. T. (2010), Linking political parties and interest groups, w: The Oxford Handbook of American Political Parties and Interest Groups, red. L. Sandy Maisel, J. M. Berry, G. C. Edwards III, s. 568-587, Oxford University Press, Oxford.

Kałużna K., Rosicki R. (2013), O interesie narodowym i racji stanu - rozważania teoretyczne, „Przegląd Politologiczny", nr 1 (2013), s. 119-128, ISSN: 1426-8876.

Klüver H. (2018), Setting the party agenda: interest groups, voters and issue attention, „British Journal of Political Science", 1-22, DOI: 10.1017/S0007123418000078.

Komisja Europejska (2020), Działania $w$ dziedzinie klimatu, Unijny system handlu uprawnieniami do emisji (EU ETS), https://ec.europa.eu/clima/policies/ets_pl, 12.07.2020.

Konopacki S. (1998), Neofunkcjonalistyczna teoria integracji politycznej Ernsta Haasa i Leona Lindberga, „Studia Europejskie, Centrum Europejskie Uniwersytetu Warszawskiego”, nr 3, s. 105-115, ISSN: 1428-149X.

Kurczewska U. (2008), Wprowadzenie, w: Deficyt demokracji w Unii Europejskiej, red. U. Kurczewska, Wydawnictwo Uniwersytetu Warszawskiego, Warszawa.

Kurczewska U. (2011), Lobbing i grupy interesu w Unii Europejskiej, Wydawnictwo Naukowe PWN, Warszawa.

Lerche Ch. O., Said A. A. Jr., (1963), Concepts of International Politics, Englewood Cliffs, Prentice Hall Inc, New Jersey.

Marshall D. (2014), Explaining interest group interactions with party group members in the European parliament: Dominant party groups and coalition formation, ,Journal of Common Market Studies", 53(2), s. 311-329, DOI: 10.1111/jcms.12163.

Ministerstwo Spraw Zagranicznych Rzeczpospolitej Polskiej, Strategia Polskiej Polityki Zagranicznej 2017-2021.

Niemann A., Schmitter P. C. (2009), European Integration Theory, Oxford University Press, Oxford.

Otjes S., Rasmussen A. (2017), The collaboration between interest groups and political parties in multi-party democracies: party system dynamics and the effect of power and ideology, „Party Politics", 23(2), s. 96-109, DOI: 10.1177/1354068814568046.

Parkinson C. N. (1958), Parkinson's Law: The Pursuit of Progress, John Murray, Londyn.

Peterson J., Shackleton M. (2012), The Institutions of the European Union, Oxford University Press, Oxford.

Pogorzelski P. (2019), Polskie centrum lobbingowe w Brukseli. Czy okaże się skutecznym narzędziem polskiej dyplomacji?, 16.05.2019, „PolskieRadio24.pl”, https://www.polskieradio24. pl/5/1222/Artykul/2310171,Polskie-centrum-lobbingowe-w-Brukseli-Czy-okaze-sieskutecznym-narzedziem-polskiej-dyplomacji, 12.07.2020.

Rosamond B. (2000), Theories of European Integration, Palgrave Macmillan, New York.

Rząsa D. (2019), Polski biznes otwiera centrum lobbingowe w Brukseli, 16.05.2019, „300Gospodarki”, https://300gospodarka.pl/news/otwarcie-business-and-science-poland-w-brukseli, 12.07.2020.

Tosiek P. (2007), Komitologia. Szczególny rodzaj decydowania politycznego, Wydawnictwo Uniwersytetu Marii Curie-Skłodowskiej, Lublin.

Traktat o Unii Europejskiej, Dz. Urz. UE, C 326, t. 55, 26 października 2012. 
Wessels B. (2004), Contestation potential of interest groups in the EU: Emergence, structure, and political alliances, w: European integration and political conflict, red. C. Hill, M. R. Steenbergen, s. 195-215, Cambridge University Press, Cambridge.

Wonka A. (2017), German MPs and interest groups in EU multilevel policy-making: the politics of information exchange, „West European Politics”, 40 (5), s. 1-21, DOI: 10.1080/01402382.2017.1303247.

\section{Streszczenie}

Głównym celem artykułu jest pokazanie deficytów związanych z obroną interesów przez aktorów niepaństwowych związanych z polską racją stanu. Ponadto artykuł przedstawia wyartykułowane i promowane interesy Polski na poziomie Unii Europejskiej. Artykuł koncentruje się także na podmiotach niepaństwowych zaangażowanych w lobbing na poziomie europejskim i krajowym. W artykule podjęto również próbę ustalenia miejsca podmiotów niepaństwowych w systemie instytucjonalnym Unii Europejskiej w kontekście wzrostu promowania polskiej racji. Oprócz wymiarów teoretycznych, artykuł ten oferuje praktyczny wgląd w funkcjonowanie polskich podmiotów niepaństwowych na poziomie europejskim, który rozwijał się w ostatnich latach.

Słowa kluczowe: polska racja stanu, aktorzy niepaństwowi, grupy interesu, lobbing, Unia Europejska

\section{Representation of non-state actors in the European Union and the Polish raison d'état}

\section{Summary}

The main aim of the article is to show the deficits related to the defense of interests by nonstate actors related to the Polish raison d'état. Moreover, the article presents the articulated and promoted interests of Poland at the European Union level. The article also focuses on non-state actors involved in lobbying at the European and national levels. The article also attempts to establish the place of non-state actors in the institutional system of the European Union in the context of increasing promotion of the Polish raison d'état. In addition to the theoretical dimensions, this article offers a practical insight into the functioning of Polish non-state actors at the European level, which has developed in recent years.

Key words: non-state actors, interest groups, lobbying, European Union, Poland 
